The Journal of Laryngology \& Otology

http://journals.cambridge.org/JLO

Additional services for The Journal of Laryngology \& Otology:

Email alerts: $\underline{\text { Click here }}$

Subscriptions: $\underline{\text { Click here }}$

Commercial reprints: Click here

Terms of use : $\underline{\text { Click here }}$

\title{
Auditory neuropathy in a patient exposed to xylene: case report
}

T H J Draper and D-E Bamiou

The Journal of Laryngology \& Otology / Volume 123 / Issue 04 / April 2009, pp 462 - 465

DOI: 10.1017/S0022215108002399, Published online: 28 April 2008

Link to this article: http://journals.cambridge.org/abstract_S0022215108002399

How to cite this article:

T H J Draper and D-E Bamiou (2009). Auditory neuropathy in a patient exposed to xylene: case report. The Journal of Laryngology \& Otology, 123, pp 462-465 doi:10.1017/S0022215108002399

Request Permissions : $\underline{\text { Click here }}$ 


\title{
Auditory neuropathy in a patient exposed to xylene: case report
}

\author{
T H J DRAPER, D-E BAMIOU*
}

\begin{abstract}
Objective: To report the case of an adult patient who developed auditory complaints following xylene exposure, and to review the literature on the effects of solvent exposure on hearing.

Case report: The patient presented with a gradual deterioration in his ability to hear in difficult acoustic environments and also to hear complex sounds such as music, over a 40-year period. His symptoms began following exposure to the solvent xylene, and in the absence of any other risk factor. Our audiological investigations revealed normal otoacoustic emissions with absent auditory brainstem responses and absent acoustic reflexes in both ears, consistent with a diagnosis of bilateral auditory neuropathy. Central test results were also abnormal, indicating possible involvement of the central auditory pathway.

Conclusions: To our knowledge, this is the first report of retrocochlear hearing loss following xylene exposure. The test results may provide some insight into the effect of xylene as an isolated agent on the human auditory pathway.
\end{abstract}

Key words: Auditory Neuropathy; Hearing; Xylene; Solvent Exposure

\section{Introduction}

Organic solvents are common in industrial environments and are used in large quantities across the world. Some of the more common solvents include xylene, toluene and styrene and can be found in household items such as paints, pharmaceuticals, adhesives, pesticides and household cleaners. However, research suggests that long term or acute exposure to solvents can have noxious, neurotoxic and ototoxic effects. ${ }^{1}$

Humans with long term or acute exposure to solvents have demonstrated hearing losses greater than would be expected for their age $\mathrm{e}^{2-6}$ and, when working in industrial environments using solvents, greater than would be expected for noise exposure alone. ${ }^{3-5,7}$ There is also evidence that solvent exposure may result in retrocochlear rather than peripheral cochlear lesions in humans. For example, impaired speech recognition scores consistent with a retrocochlear pattern and/or abnormal cortical responses and/or abnormal reflex decay have been reported in populations working with toluene, ${ }^{5}$ jet fuels, ${ }^{8}$ styrene ${ }^{9}$ and mixtures of solvents. ${ }^{8,10-12}$

It is now documented that solvents should be considered as individual substances with different specific toxicities, ${ }^{12}$ and that solvents may act on transmitters specific for certain neural structures and pathways. ${ }^{10}$ For example, significantly delayed auditory brainstem responses (ABRs) were measured in a group of normally hearing workers professionally exposed to toluene. ${ }^{13}$

Xylene is a solvent structurally related to toluene. ${ }^{14}$ There is no literature on the effect of xylene, acting as a single agent, on the auditory pathway in humans.

We present a case of an adult patient with hearing loss and auditory complaints attributed to auditory nerve pathology, i.e. auditory neuropathy or dys-synchrony. This patient's hearing complaints developed at the time of xylene exposure, in the absence of any other risk factors for auditory neuropathy or dys-synchrony (as per his medical history).

\section{Case report}

A 60-year-old man presented to the otoneurology department with a 40-year history of hearing difficulties. His symptoms had begun in his 20 s while researching for his $\mathrm{PhD}$ and after exposure to the solvent xylene. He had worked in a small basement hut where xylene leaked into a water tank and escaped into the atmosphere. It was estimated that this exposure had occurred over a six-month period; the basement hut had been small with little or no ventilation.

A few months after the xylene exposure, the patient had noticed problems hearing in the presence of background noise. His symptoms had gradually deteriorated over time. However, he had been discharged from audiology departments on two occasions due to normal pure tone audiometry results. He had been diagnosed with auditory neuropathy or dys-synchrony at the age of 50 years, at which time he had tried both analogue and digital hearing aids but found them of no benefit.

On presentation to our clinic in March 2006, the patient described an inability to hear speech in the presence of noise and to understand people with accents, and the need to lip-read and concentrate when anyone spoke to him. He had given up using the telephone and avoided noisy social situations. The patient had no family history 
of early onset hearing impairment. He could not recall any other significant event or illness before his hearing problems began.

The patient's medical history included a right-sided sphenoid wing meningioma removal in October 2005. Due to the tumour's location, it was deemed highly unlikely that this had caused the patient's audiological symptoms. No neurological impairments were identified and the patient had normal nerve conduction. No central nervous system deficits or sense impairment (often associated with solvent exposure) were identified. Previous magnetic resonance imaging and computed tomography (CT) scans, performed following surgery, did not show any residual tumour and were otherwise normal.

Pure tone audiometry and acoustic reflex threshold results are illustrated in Figure 1. In this patient, the combination of absent or raised ( $>110 \mathrm{dBHL}$ ) ipsi- or contralateral acoustic reflex threshold and absent ABR in the presence of otoacoustic emissions was consistent with the diagnosis of bilateral auditory neuropathy or dyssynchrony. ${ }^{15,16}$ Maximum speech recognition scores of 66 and 63 per cent at $60 \mathrm{dBHL}$ were present on the right and left respectively, with a significant rollover of 55 and 5 per cent at higher intensities; this was worse than would be predicted from the audiogram. ${ }^{17}$ Poor temporal processing was demonstrated by this patient's inability to complete gaps in noise testing, ${ }^{18}$ which had to be abandoned due to the patient's random answers (Table I). Central auditory processing tests, ${ }^{19}$ which are sensitive to lesions of the central auditory pathway, were abnormal in at least one ear for each test (Table I).

\section{Discussion}

This case report presents a sequence of events and facts that may be linked, and the authors are aware that there is no hard evidence of pathology caused by xylene exposure. Our subject was exposed to xylene over a relatively small time scale (six months), and there is no quantitative information regarding the concentration of xylene in the atmosphere at the time (although the laboratory was small and inadequately ventilated). However, Dick reported that there is no real definition of what is regarded as a significant exposure to solvents, and no verdict on whether the important determinant of adverse effects is the lifetime (cumulative) exposure or the peaks (intensity) of exposure. ${ }^{1}$ In addition, the subject could have idiopathic auditory neuropathy or dys-synchrony, although the majority of reported cases (80 per cent) present in conjunction with specific medical risk factors and generalised neuropathic disorders. ${ }^{20}$ Despite these factors, reporting this case may be of some importance, given the clinical setting, regarding the possible specific toxicity of xylene on the auditory nerve and/or central auditory system in humans.

Auditory neuropathy or dys-synchrony is defined as reduced and/or asynchronous auditory nerve function, in the presence of normal outer hair cell function. ${ }^{15}$ The
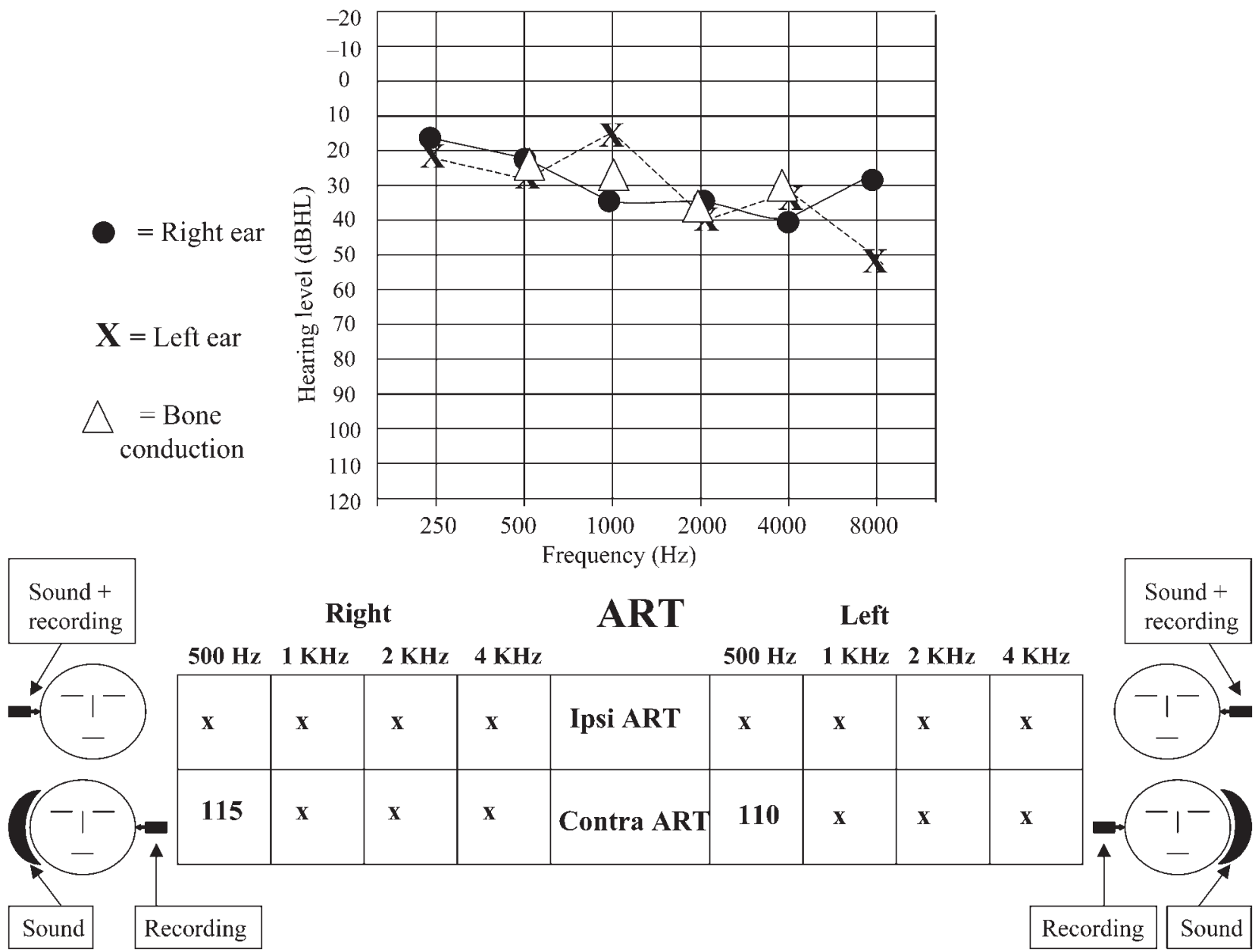

FIG. 1

Pure tone audiogram and acoustic reflexes (ARTs) obtained in March 2006. 
TABLE I

CENTRAL AUDITORY PROCESSING TESTS AND RESULTS

\begin{tabular}{|c|c|c|c|}
\hline Test & Description & $\mathrm{Pt}$ response & Score \\
\hline FPT & $\begin{array}{l}\text { Presentation of } 3 \text {-tone sequence } \\
\text { (varied combination of low } \\
\text { frequency }(880 \mathrm{~Hz}) \& \text { high } \\
\text { frequency }(1122 \mathrm{~Hz}) \text { stimuli) } \\
30 \text { trials per ear } \\
\text { Pass rate } 80 \% \text { correct }\end{array}$ & $\begin{array}{l}\text { Description of each sequence } \\
\quad \text { (e.g. high, low, high) }\end{array}$ & $\begin{array}{l}80 \% \text { right } \\
53 \% \text { left }\end{array}$ \\
\hline DPT & $\begin{array}{l}\text { Presentation of 3-tone sequence } \\
\quad \text { (varied combination of a long } \\
\quad \text { duration }(500 \mathrm{~ms}) \text { and a short } \\
\quad \text { duration }(250 \mathrm{~ms})) \\
\text { Interstimulus interval }=330 \mathrm{~ms} \\
30 \text { trials per ear } \\
\text { Pass rate } 70 \% \text { correct }\end{array}$ & $\begin{array}{l}\text { Description of each sequence } \\
\text { (e.g. long, long, short) }\end{array}$ & $\begin{array}{l}63 \% \text { right } \\
73 \% \text { left }\end{array}$ \\
\hline GIN & $\begin{array}{l}\text { 6-s burst of white noise containing } 0-3 \\
\text { gaps varying in duration }(2-20 \mathrm{~ms}) \\
\& \text { timing within the noise } \\
36 \text { trials each ear } \\
\text { Pass rate: shortest gap detection } \leq 6 \mathrm{~ms} \\
\text { in at least } 50 \% \text { of trials (i.e. at least } \\
3 / 6 \text { trials) }\end{array}$ & $\begin{array}{l}\text { Identification of number of gaps heard } \\
\text { within noise }\end{array}$ & $\begin{array}{l}\text { Abandoned as patient gave random } \\
\text { answers }\end{array}$ \\
\hline
\end{tabular}

$\mathrm{Pt}=$ patient $\mathrm{FPT}=$ frequency pattern test $;{ }^{19} \mathrm{DPT}=$ duration pattern test $;{ }^{19} \mathrm{GIN}=$ gaps in noise test. ${ }^{18}$ See text and references for further details.

possible sites of lesion in this condition include the cochlear inner hair cells, the synapse between the inner hair cells and the type I auditory nerve fibres, and the auditory nerve itself. ${ }^{20}$ The mechanism of auditory dysfunction may vary between individuals, and is thought to relate to either a dys-synchrony of the auditory nerve (e.g. due to myelin damage) or a reduction in the numbers of neural elements contributing to the volume-conducted response (e.g. due to axon-related neuropathies and inner hair cells lesions).

An inability to follow temporal fluctuations is likely to be the underlying cause for the poor speech recognition experienced by patients with auditory neuropathy or dyssynchrony, ${ }^{21}$ this was demonstrated by the inability of our patient to complete gaps in noise testing. The abnormalities detected in the central auditory processing tests may be attributed to disordered auditory nerve input and/or central auditory involvement. However, in view of the potential toxicity of solvents recorded previously at this higher level, central involvement at the level of the auditory cortex cannot be ruled out. Therefore, we may have a mixed picture: intact cochlea, impaired auditory nerve, but also possible impairment at the level of the brainstem and above.

In humans, many studies have investigated the effect of mixed solvents (including xylene) on the auditory system, but none have investigated the effect of xylene acting as a single agent. Xylene is structurally related to toluene, ${ }^{14}$ and some human studies have examined the auditory pathways affected by this latter solvent more closely. Morata et al. carried out various audiological tests on workers from a printing factory who had been exposed to toluene or mixed solvents. ${ }^{5}$ The results demonstrated an interaction between toluene and noise exposure which resulted in a greater risk of hearing impairment. Interestingly, the observed hearing losses were only mild $(<40 \mathrm{dBHL})$ and reflexes were present in most cases. However, the noise plus toluene group had a greater percentage of cases with reflex decay, particularly for contralateral stimulation, compared with ipsilateral stimulation. Morata and colleagues suggested that, in these workers, the observed hearing loss showed an additional central component at the intra-axial brainstem level.
Metrick and Brenner reported the cases of two young adults with neurological disorders secondary to spray paint (toluene) abuse. These patients had high frequency hearing losses and normal reflexes. ${ }^{6}$ Their ABRs showed the presence of waves I and II but the absence of later waves, suggesting bilateral lower brainstem dysfunction. ${ }^{6}$ Both patients had abnormal CT scans showing evidence of brainstem atrophy.

- Audiological studies of humans exposed to solvents have demonstrated peripheral hearing losses and/or impairment of the central auditory pathway (i.e. brainstem and above)

- Solvents should be considered as individual substances with specific toxicities; however, it is difficult to test for this in humans

- This is the first report on the possible effects of xylene acting as a single agent on the auditory pathway in a human with retrocochlear hearing loss

A study by Abbate et al. reported results that perhaps compare most closely to our case. These authors found a significant delay in ABR latencies, and a significant delay in interpeak latencies (compared with a control group) for waves I, III and V at click rates of 11.1 and 90 clicks per second, for workers professionally exposed to toluene. ${ }^{13}$ Both groups were controlled for noise exposure and neurological diseases, and all workers had thresholds below $20 \mathrm{~dB}$. Interestingly, waves I-III were more significantly altered than wave V. Central auditory tests were not carried out. Abbate and colleagues proposed that the wave I alterations found could be attributed to the solvent's effect on the peripheral receptor structures of the auditory nerve, because of its liposolubility. This could impair the membrane integrity of the peripheral receptor and/or modify the structure of the junctional site, resulting in alteration of the stimulus transduction mechanism. Xylene is more liposoluble than toluene, ${ }^{14}$ due to its 
structural similarity, it could be proposed that xylene has a similar mechanism of toxicity on the human auditory nerve.

This is the first report of retrocochlear hearing loss in a human adult patient following xylene exposure and in the absence of any other risk factor. Caution should be noted regarding the length of time the subject was exposed to the solvent, and the fact that no inferences can be made about the concentration or biochemical properties of the solvent. However, the test results may provide some insight into the effect of xylene as an isolated agent on the human auditory pathway.

\section{Acknowledgement}

Many thanks to the patient involved in this study for his time and information.

\section{References}

1 Dick FD. Solvent neurotoxicity. Occup Environ Med 2006; 63:221-6

2 Mosche S, Bitchatchi E, Goshen J, Attis J. Neuropathy in an artist exposed to organic solvents in paints: a case study. Arch Environ Health 2002;57:127-9

3 Sliwinska-Kowalska M, Zamyslowska-Szmytke E, Szymczak W, Kotylo P, Fiszer M, Dudarewicz A et al. Hearing loss among workers exposed to moderate concentration of solvents. Scand J Work Environ Health 2001;27:335-42

4 Jacobsen P, Hein HO, Suadicani P, Parving A, Gyntelberg F. Mixed solvent exposure and hearing impairment: an epidemiological study of 3284 men. The Copenhagen male study. Occup Med 1993;43:180-4

5 Morata TC, Dunn DE, Kretschmer LW, Lemasters GK, Keith RW. Effects of occupational exposure to organic solvents and noise on hearing. Scand J Work Environ Health 1993;19:245-54

6 Metrick SA, Brenner RP. Abnormal brainstem auditory evoked potentials in chronic paint sniffers. Ann Neurol 1982;12:553-6

7 Morata TC, Engel T, Durao A, Costa TRS, Krieg EF, Dunn DE et al. Hearing loss from combined exposures among petroleum refinery workers. Scand Audiol 1997; 26:141-9

8 Odkvist LM, Arlinger SD, Edling C, Larsby B, Bergholz LM. Audiological and vestibulo-oculomotor findings in workers exposed to solvents and jet fuel. Scand Audiol 1987;16:75-81

9 Moller C, Odkvist LM, Larsby B, Tham R, Ledin T, Bergholtz L. Otoneurological findings in workers exposed to styrene. Scand J Work Environ Health 1990;16:189-94

10 Odkvist LM, Bergholtz LM, Ahlfeldt H, Anderson B, Edling C, Strand E. Otoneurological and audiological findings in workers exposed to industrial solvents. Acta Otolaryngol (Stockh) 1982;93(suppl 386):249-51
11 Moller C, Odkvist LM, Thell J, Larsby B, Hyden D, Bergoltz $\mathrm{L}$ et al. Otoneurological findings in psycho-organic syndrome caused by industrial solvent exposure. Acta Otolaryngol (Stockh) 1989;107:5-12

12 Niklasson M, Arlinger S, Ledin T, Moller C, Odkvist L, Flodin U et al. Audiological disturbances caused by longterm exposure to industrial solvents. Relation to the diagnosis of toxic encephalopathy. Scand Audiol 1998;27: $131-6$

13 Abbate C, Giorgianni C, Munano F, Brecciaroli R. Neurotoxicity induced by exposure to toluene. An electrophysiological study. Int Arch Occup Environ Health 1993;64: 389-92

14 Pryor GT, Rebert CS, Howd RA. Hearing loss in rats caused by inhalation of mixed xylenes and styrene. J Appl Toxicol 1987;7:55-61

15 Madden C, Rutter M, Hilbert L Greinwald JH Jr, Choo DI. Clinical and audiological features in auditory neuropathy. Arch Otolaryngol Head Neck Surg 2002;128:1026-30

16 Starr A, Picton T, Kim R. Pathophysiology of auditory neuropathy. In: Sininger Y, Starr A, eds. Auditory Neuropathy: a New Perspective on Hearing Disorders. San Diego: Singular Publishing, 2001;67-82

17 Dubno J, Lee F, Klein A, Matthews LJ, Lam CF. Confidence limits for maximum word-recognition scores. J Speech Hear Res 1995;38:490-502

18 Musiek FE, Shinn JB, Jirsa R, Bamiou D, Baran JA, Elena J. GIN (Gaps in Noise) test performance in subjects with confirmed central auditory nervous system involvement. Ear Hear 2005;26:608-18

19 Musiek FE. Frequency (pitch) and duration pattern tests. J Am Acad Audiol 1994;5:265-8

20 Rance G, Aud D. Auditory neuropathy/dys-synchrony and its perceptual consequences. Trends in Amplification 2005; 9:1-43

21 Zeng F, Oba S, Garde S, Yvonne S, Starr A. Temporal and speech processing deficits in auditory neuropathy. Neuroreport 1999;10:3429-35

Address for correspondence:

Miss Tracy H J Draper,

Audiology Department,

Royal Sussex County Hospital,

Eastern Road,

Brighton BN2 5BE, UK.

Fax: 01273664806

E-mail: tracy.draper@bsuh.nhs.uk

Miss T H J Draper takes responsibility for the integrity

of the content of the paper.

Competing interests: None declared 